\title{
PENGARUH MODEL PEMBELAJARAN KOOPERATIF TIPE SCRAMBLE BERBANTUAN MEDIA VIDEO ANIMASI TERHADAP KOMPETENSI PENGETAHUAN PPKn
}

\author{
I Kd. Mega Putra Harapan ${ }^{1}$, I G. A. Agung Sri Asri ${ }^{2}$, M.G. Rini Kristiantari ${ }^{3}$ \\ Jurusan Pendidikan Guru Sekolah Dasar, Universitas Pendidikan Ganesha, Singaraja, Indonesia
}

\section{Abstrak}

Penelitian ini bertujuan untuk mengetahui perbedaan yang signifikan kompetensi pengetahuan PPKn kelompok siswa yang dibelajarkan menggunakan model pembelajaran kooperatif tipe scramble berbantuan media video animasi dengan kelompok siswa yang dibelajarkan secara konvensional pada siswa kelas V SD Gugus V Jenderal Sudirman Denpasar Selatan Tahun Ajaran 2018/2019. Jenis penelitian ini adalah penelitian eksperimen semu dengan rancangan non-ekuivalen control group desaign. Populasi penelitian ini adalah seluruh siswa kelas V SD Gugus V Jenderal Sudirman Denpasar Selatan Tahun Ajaran 2018/2019 yang berjumlah 332 siswa. Penentuan kelompok eksperimen dan kontrol dilakukan dengan teknik random sampling. Data kompetensi pengetahuan PPKn siswa dikumpulkan dengan instrumen berupa tes objektif pilihan ganda biasa sebanyak 30 soal yang sudah divalidasi. Hasil analisis menunjukkan terdapat perbedaan yang signifikan kompetensi pengetahuan PPKn antara kelompok siswa yang dibelajarkan menggunakan model pembelajaran kooperatif tipe scramble berbantuan media video animasi dengan kelompok siswa yang dibelajarkan secara konvensional pada siswa kelas V SD Gugus V Jenderal Sudirman Denpasar Selatan Tahun Ajaran 2018/2019. Hal tersebut dibuktikan dengan hasil nilai thitung $=2,825>\operatorname{ttabel}(\mathrm{a}=0,05, \mathrm{dk}=75)=1,992$. Rata-rata gain skor ternormalisasi kompetensi pengetahuan PPKn kelompok eksperimen yang dibelajarkan menggunakan model pembelajaran kooperatif tipe scramble berbantuan media video animasi adalah $\overline{\mathrm{X}} 1=0,309>\overline{\mathrm{X}} 2=0,196$ kelompok kontrol yang dibelajarkan secara konvesional dengan perbedaan sebesar 0,113. Dengan demikian dapat disimpulkan bahwa model pembelajaran kooperatif tipe scramble berbantuan media video animasi berpengaruh terhadap kompetensi pengetahuan PPKn siswa kelas V SD Gugus V Jenderal Sudirman Denpasar Selatan Tahun Ajaran $2018 / 2019$
Keywords:

model scramble, video

animasi, PPKn

\section{Pendahuluan}

Pendidikan mempunyai peranan yang sangat penting dalam kehidupan manusia. Pendidikan berusaha mengubah tingkah laku seseorang dalam perpikir dan bertindak atau bertingkah laku. Pendidikan harus diarahkan untuk meningkatkan kemampuan manusia dalam mengatasi masalahmasalah yang berkaitan dengan kehidupannya. Pendidikan merupakan suatu proses untuk membantu manusia dalam mengembangkan dirinya, sehingga mampu menghadapi segala perubahan dan permasalahan dengan sikap terbuka serta pendekatan-pendekatan yang kreatif tanpa harus kehilangan identitas dirinya. Undang-Undang No. 20 Tahun 2003 tentang Sisdiknas, disebutkan bahwa: 
pendidikan merupakan usaha sadar dan terencana untuk mewujudkan suasana belajar dan proses pembelajaran agar peserta didik secara aktif mengembangkan potensi dirinya untuk memiliki kekuatan spiritual keagamaan, pengendalian diri, kepribadian, kecerdasan, akhlak mulia, serta keterampilan yang diperlukan dirinya, masyarakat, bangsa dan negara.

Dalam menanggapi kestrategisan peran pendidikan tersebut, pemerintah telah merumuskan fungsi dan tujuan dari pendidikan yang dijelaskan dalam Sisdiknas No. 20 Tahun 2003 pasal 3 sebagai berikut, pendidikan nasional berfungsi mengembangkan kemampuan dan membentuk watak serta peradaban bangsa yang bermartabat dalam rangka mencerdaskan kehidupan bangsa, bertujuan untuk berkembangnya potensi peserta didik agar menjadi manusia yang beriman dan bertakwa kepada Tuhan Yang Maha, berakhlak mulia, sehat, berilmu, cakap, kreatif, dan menjadi warga negara yang demokratis serta bertanggung jawab. Salah satu upaya pemerintah untuk memperbaiki kualitas mutu pendidikan agar dapat mencetak manusia yang berkaulitas dan mampu proaktif menjawab tantangan zaman yang selalu berubah dengan adanya kurikulum.

Dalam Permendikbud nomor 57 tahun 2014 lampiran 1 menetapkan kurikulum pada Sekolah Dasar/Madrasah Ibtidaiyah yang telah diajarkan sejak tahun ajaran 2013/2014 disebut kurikulum 2013 Sekolah Dasar/Madrasah Ibtidiayah. Proses pembelajaran pada kurikulum 2013 untuk semua jenjang dilaksanakan dengan menggunakan pendekatan ilmiah (saintifik). Kurikulum 2013 bertujuan untuk mempersiapkan manusia Indonesia agar memiliki kemampuan hidup sebagai pribadi dan warga negara yang beriman, produktif, kreatif, inovatif, dan afektif serta mampu berkonstribusi pada kehidupan bermasyarakat, berbangsa, bernegara dan peradaban dunia. Dalam kurikulum 2013 siswa dituntut melalui beberapa proses secara aktif mencari, mengolah, mengkonstruksi, dan menerapkan pengetahuan.

Dengan demikian, mereka dapat memahami suatu konsep dengan utuh bukan hanya sebagai pengetahuan tetapi juga dapat diterapkan melalui kegiatan-kegiatan dalam pembelajaran. Salah satu mata pelajaran tersebut adalah mata pelajaran Pendidikan Pancasila dan Kewarganegaraan atau (PPKn).Pembelajaran Pendidikan Pancasila dan Kewarganegaraan (PPKn) selain sebagai salah satu bidang ilmu dalam dunia pendidikan juga merupakan salah satu bidang studi yang sangat penting, baik bagi siswa maupun bagi pengembangan bidang keilmuan yang lain. Kedudukan PPKn dalam dunia pendidikan sangat besar manfaatnya karena PPKn dapat membantu kemampuan siswa dalam mengembangkan serta membekali pengetahuan siswa. PPKn pada umumnya merupakan pembelajaran yang di anggap mudah tetapi pada dasarnya membingungkan siswa. Kondisi umum ini sering dijumpai oleh guru yang mengajar materi PPKn.

Dari hasil observasi yang dilakukan pada tanggal 20 November 2018 pada proses pembelajaran di kelas V SD Gugus V Jenderal Sudirman Denpasar Selatan dan juga wawancara dengan guru-guru mengenai nilai kompetensi pengetahuan pada muatan mata pelajaran IPA, IPS, Bahasa Indonesia, Matematika, dan PPKn. Dari data beberapa kompetensi pengetahuan yang telah dihimpun tersebut ditemukanlah nilai kompetensi pengetahuan PPKn yang masih berada dibawah KKM. Hal ini dikarenakan metode pembelajaran yang digunakan selama ini kurang bervariasi bahkan masih bersifat monoton, sehingga menimbulkan kondisi pembelajaran yang kurang menarik dan menyenangkan serta kurang menantang kemampuan berpikir siswa, siswa cenderung merasa bosan, kurang termotivasi dalam mengikuti proses pembelajaran yang akan membawa pengaruh terhadap pencapaian kompetensi pengetahuan PPKn.

Berdasarkan hal tersebut dari nilai KKM yang dipatokan untuk muatan materi PPKn yaitu 70, diperoleh bahwa kompetensi pengetahuan PPKn yang diambil dari nilai raport semester I (satu) dari 332 siswa yang mendapat nilai A sebanyak 69 siswa, siswa yang mendapat nilai B sebanyak 91 siswa, siswa yang mendapat nilai $C$ sebanyak 172 siswa. Berdasarkan yang diperoleh, 160 siswa atau 48,19\% yang sudah mencapai nilai yang diharapkan. Sedangkan, 172 siswa atau 51,81\% yang belum mampu menunjukan hasil belajar yang baik atau memperoleh predikat B. Berkaitan dengan banyaknya faktor yang mempengaruhi hal tersebut, diantaranya model yang digunakan dalam proses pembelajaran kurang inovatif dan bervariasi yang membuat siswa kurang aktif dalam proses pembelajaran PPKn, proses pembelajaran PPKn belum maksimal dalam memberikan kesempatan kepada siswa untuk berpikir kritis dan bertindak kreatif sehingga kurangnya siswa dalam memahami materi kompetensi pengetahuan PPKn yang dibelajarkan. Demikian, dipandang perlu peningkatkan kompetensi pengetahuan PPKn.

Untuk mengatasi permasalahan tersebut maka dilakukan penelitian sebagai pemecahan masalah tersebut. Untuk mengoptimalkan kompetensi pengetahuan PPKn siswa perlu diadakan situasi 
belajar yang kondusif, menyenangkan, menantang, dan merangsang minat siswa untuk lebih antusias berperan aktif dalam proses pembelajaran. Salah satu alternatif yang digunakan untuk pemecahan masalah tersebut yaitu dengan menggunakan model pembelajaran kooperatif tipe scramble, merupakan model pembelajaran yang mengajak siswa untuk bekerja secara berkelompok untuk berbagi ilmu yang dimiliki serta belajar secara individu.

Pembelajaran kooperatif menuntut siswa belajar secara berkelompok untuk berkerja secara kolaboratif untuk mencapai tujuan bersama.

Kurniasih (2016:99) menyatakan, model pembelajaran scramble adalah model pembelajaran yang tampak lebih mirip dengan model pembelajaran word square, hanya saja terlihat berbeda karena jawaban soal tidak dituliskan di dalam kotak-kotak jawaban, tetapi sudah dituliskan namun dengan susunan yang acak. Siswa hanya ditugaskan mengkoreksi (membolak-balik huruf) jawaban tersebut sehingga menjadi jawaban yang tepat dan benar.

Adapun kelebihan dari model pembelajaran scramble menurut Kurniasih, (2016:100) yaitu, (a) siswa sangat terbantu dalam mencari jawaban, (b) mendorong siswa untuk belajar mengerjakan soal tersebut, (c) semua siswa dapat terlibat aktif, (d) siswa dapat saling membantu dalam memahami materi pembelajaran dengan bantuan teman-temanya sesama siswa dan, (e) meningkatkan sikap disiplin siswa.

Dalam penggunaan model pembelajaran kooperatif tipe scramble guru juga dapat menggunakan media pembelajaran untuk membantu proses pembelajaran agar mudah dipahami oleh peserta didik. Menurut Arsyad (2010: 3) "media adalah bagian yang tidak terpisahkan dari proses belajar mengajar demi terciptanya tujuan pendidikan pada umumnya dan tujuan pembelajaran di sekolah pada khususnya". Salah satu media yang dapat digunakan dalam proses pembelajaran adalah video animasi, dimana video animasi merupakan media yang memberikan tampilan gambar bergerak dalam proses pembelajaran yang nantinya dapat menarik perhatian peserta didik dalam proses pembelajaran, dimana dalam penggunaanya dibantu oleh pemandu guru.

Berdasarkan permasalahan terhadap kompetensi pengetahuan PPKn maka dari itu digunakanlah model

pembelajaran kooperatif tipe scramble berbantuan media video animasi yang merupakan suatu inovasi pembelajaran untuk meningkatkan pemahaman siswa terhadap proses pembelajaran, menciptakan pembelajaran yang dapat mengaktifkan siswa, menumbuhkan rasa senang siswa terhadap pembelajaran dan meningkatakan motivasi siswa dalam proses pembelajaran. Pernyataan ini turut didukung dengan penelitian yang sejalan dengan penelitian yang dilakukan oleh Widiantari pada tahun 2013 yang berjudul "Pengaruh Model Pembelajaran Scramble Berbantuan Media Video Terhadap Hasil Belajar IPA Siswa Kelas IV SD di Gugus V Kecamatan Buleleng Tahun Pelajaran 2012/2013". Menyatakan bahwa penerapan model pembelajaran scramble berbantuan media video berpengaruh terhadap hasil belajar IPA kelas IV SD di Gugus V Kecamatan Buleleng. Hal ini terlihat dari $\left(\mathrm{t}_{\text {hitung }} \mathrm{g}=7,90>\mathrm{t}_{\text {tabel }}=2,00\right.$ ) dimana rata-rata skor hasil belajar IPA kelas yang mengikuti pembelajaran dengan model pembelajaran scramble berbantuan media video adalah 22,26 yang berada pada kategori sangat tinggi, sedangkan kelas yang mengikuti pembelajaran dengan model pembelajaran Konvensional adalah 13,56 yang berada pada kategori cukup. Dan sejenis dengan penelitian yang dilakukan oleh widi astuti yang menyatakan terdapat perbedaan yang signifikan hasil belajar IPS antara siswa yang dibelajarkan dengan model pembelajaran kooperatif tipe scramble berbantuan mind mapping dan siswa yang dibelajarkan secara konvensional pada siswa kelas V SD di Gugus I Kecamatan Banjar Kabupaten Buleleng Tahun Pelajaran 2016/2017.

Berdasarkan paparan tersebut, maka dilakukan penelitian untuk mengoptimalkan kompetensi pengetahuan PPKn siswa melalui penelitian dengan judul "Pengaruh Model Pembelajaran Kooperatif Tipe Scramble Berbantuan Media Video Animasi Terhadap Kompetensi Pengetahuan PPKn Siswa Kelas V SD Gugus V Jenderal Sudirman Denpasar Selatan Tahun Ajaran 2018/ 2019”.

\section{Metode}

Penelitian ini dilaksanakan di SD Gugus V Jenderal Sudirman Denpasar Selatan. Lokasi ini dipilih karena memiliki aspek pendukung agar penelitian dapat berjalan dengan baik. Adapun aspek pendukung tersebut antara lain adalah seluruh SD Gugus V Jenderal Sudirman secara serentak 
menerapkan kurikulum 2013, lokasi sekolah dalam 1 Gugus yang cukup berdekatan sehingga lebih memudahkan dalam melaksanakan penelitian, dan juga tidak terdapatnya kelas unggulan di setiap sekolah dalam Gugus tersebut.Jenis penelitian ini adalah penelitian kuantitatif yaitu penelitian eksperimen dengan rancangan quasi experimental design.

Sugiyono (2012:114) menjelaskan bahwa quasi experimental design mempunyai kelompok kontrol, namun tidak dapat berfungsi sepenuhnya untuk mengontrol variabel-variabel luar yang memengaruhi pelaksanaan eksperimen. Hal ini dikarenakan kemampuan peneliti dalam mengamati perilaku siswa sangat terbatas terutama ketika siswa berada di luar sekolah (rumah), peneliti juga tidak memiliki kemampuan untuk mengetahui persepsi siswa terhadap perlakukan secara pasti.Dengan demikian, rancangan eksperimen semu Nonequivalent Control Group Design digambarkan sebagai berikut.

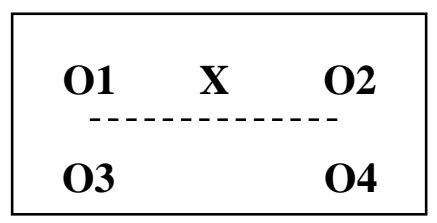

\section{Gambar 1 \\ Rancangan Penelitian Nonequivalent Control Group Design}

(Sumber : Sugiyono, 2012:116)

Keterangan :

$$
\begin{aligned}
& O_{1}=\text { pre test pada kelompok eksperimen } \\
& O_{2}=\text { post test pada kelompok eksperimen } \\
& O_{3}=\text { pre test pada kelompok kontrol } \\
& O_{4}=\text { post test pada kelompok kontrol } \\
& \mathrm{X}=\text { Perlakuan dengan model pembelajaran scramble berbantuan }
\end{aligned}
$$

Populasi merupakan semua anggota kelompok yang digunakan peneliti sebagai subjek penelitian dalam satu tempat secara terencana yang menjadi target kesimpulan dari hasil akhir suatu penelitian. Sugiyono (2012:117) menyatakan populasi sebagai wilayah generalisasi yang terdiri dari objek atau subjek yang mempunyai kualitas dan karakteristik yang ditetapkan peneliti untuk dipelajari dan ditarik kesimpulannya. Sedangkan menurut Dantes (2012: 37) populasi adalah sejumlah kasus yang memenuhi seperangkat kriteria tertentu, yang ditentukan peneliti.

Berdasarkan pendapat-pendapat tersebut dapat dirangkum populasi adalah keseluruhan objek atau subjek penelitian sebagai sumber data dengan kriteria tertentu yang ditetapkan oleh peneliti untuk dipelajari dan ditarik kesimpulannya.Populasi dalam penelitian ini adalah seluruh siswa kelas V SDGugus V Jenderal Surdirman Denpasar Selatan tahun ajaran 2018/2019. Setelah mengetahui populasi langkah selanjutnya adalah menentukan sampel penelitian. Menurut Sugiyono (2012: 118) mengemukakan "Sampel adalah bagian dari jumlah dan karakteristik yang dimiliki oleh populasi tersebut". Sejalan dengan pendapat tersebut, Agung (2014: 69) menyatakan sampel adalah sebagian dari populasi yang diambil, yang dianggap mewakili seluruh populasi dan diambil dengan menggunakan teknik tertentu. 
Jadi, berdasarkan pendapat tersebut dapat dirangkum bahwa sampel adalah sejumlah kelompok kecil yang mewakili populasi untuk dijadikan objek penelitian.

Teknik pengambilan sampel yang digunakan dalam penelitian ini adalah teknik random sampling. Menurut Agung (2014: 72), teknik ini dilakukan dengan cara mencampur subjek-subjek di dalam populasi sehingga semua subjek dianggap sama, semua subjek mendapat hak yang sama untuk memperoleh kesempatan dipilih menjadi anggota sampel. Teknik random sampling dapat dilakukan dengan beberapa cara yaitu undian, ordinal, bilangan random. Pada penelitian ini, tidak dilakukannya pengacakan individu melainkan hanya pengacakan kelas sehingga setiap kelas mendapatkan peluang yang sama untuk menjadi sampel penelitian.

Hal ini dikarenakan jumlah populasi besar (banyak) dan tidak dapat dilakukan pengubahan kelas yang telah terbentuk sebelumnya sehingga kelas dipilih sebagaimana kelas yang sudah terbentuk tanpa adanya campur tangan peneliti untuk pengacakan individu. Selain itu, hal ini dilakukan untuk mengurangi pengaruh dari keadaan siswa mengetahui dirinya dilibatkan dalam eksperimen sehingga penelitian ini benar-benar menggambarkan pengaruh perlakuan yang diberikan. Sampel dalam penelitian ini adalah siswa kelas V SD Negeri 13 Sesetan dan Siswa kelas V SD Negeri 2 Serangan.Selanjutnya sampel di berikan pretestuntuk mendapatkan sampel penelitian sehingga sampel penelitian merupakan kelompok yang setara secara akademik.

Dari hasil scor pretestakan dijadikan nilai awal untuk untuk menganalisis data gain scor dinormalisasi dari kelompk ekperimen dan kelompok kontrol dengan teknik undian. Berdasarkan hasil undian diperoleh kelas V SD negeri 13 sesetan sebagi kelompok eksperimen dan kelas V SD Negeri 2 serangan sebagai kelompok kontrol. Metode pengumpulan data merupakan cara atau teknik yang dilakukan dalam mengumpulkan data penelitian. Dalam penelitian ini, metode pengumpulan data yang digunakan adalah metode tes. "Metode tes adalah cara memperoleh data yang berbentuk suatu tugas yang harus dikerjakan oleh seorang atau kelompok orang yang dites (testee), dan dari tes dapat menghasilkan suatu skor atau nilai" (Agung, 2014: 92). Sudijono (2015: 66) menyatakan,Test adalah alat atau prosedur yang di pergunakan dalam rangka pengukuran dan penilaian; testing berarti saat dilaksanakan atau peristiwa berlangsungnya pengukuran dan penilaian; sedangkan teste (mufrad) dan testees (jama) adalah pihak yang sedang dikenai tes (=peserta tes=seperta ujian), atau pihak yang sedang dikenai percobaan(=tercoba).

Tujuan metode tes adalah untuk mengetahui tingkat keberhasilan proses pembelajaran yang telah dilaksanakan. Jadi, dapat dirangkum bahwa metode tes merupakan salah satu alat yang digunakan untuk mengukur kemampuan seseorang. Tes yang baik harus mampu mengukur apa yang akan diukur.

Data yang dikumpulkan dalam penelitian ini adalah scor kompetensi pengetahuan PPKn. Pengumpulan data kompetensi pengetahuan PPKn ini dilakukan pada siswa kelas V SD Gugus V Jenderal sudirman Denpasar Selatan Tahun Ajaran 2018/2019.

Penelitian ini memiliki dua variabel, yaitu variable terikat dan variabel bebas. Variabel terikat dipengaruhi oleh variabel bebas. Variabel terikat dalam penelitian ini adalah kompetensi pengetahuan PPKn. Sedangkan, varibel bebas adalah variabel yang menyebabkan atau mempengaruhi perubahan dan timbulanya variabel terikat yang akan di amati. Variabel bebas dalam penelitian ini dalah model pembelajaran kooperatif tipe scramble berbantuan media video animasi. 
Sebelum dilakukan penyebaran tes, maka tes terlebih dahulu diuji coba. Uji coba dilaksanakan untuk menguji kelayakan instrumen tes yang digunakan pada penelitian ini.untuk memperoleh data penelitian yang akurat makan penggunaan instrumen tes dalam penelitian ini harus memenuhi syarat validitas. Uji validitas berkaitan dengan ketepatan alat ukur instrumen. Sugiyono (2012: 363) mengemukakan bahwa Validitas merupakan derajat ketepatan antara data yang terjadi pada objek penelitian dengan data yang dapat dilaporkan oleh peneliti. Suatu instrumen (tes) dikatakan valid jika instrumen tersebut dapat digunakan untuk mengukur apa yang seharusnya diukur.

Jenis tes yang digunakan dalam penelitian ini adalah tes objektif tipe Pilihan Ganda Biasa (PGB) dengan empat opsi (pilihan jawaban) dan satu opsi diantara empat opsi tersebut merupakan jawaban yang tepat.

Tes tipe pilihan ganda biasa yang diuji coba terdiri dari 40 butir tes. Tes objektif tipe pilihan ganda biasa yang digunakan bersifat terstandar dengan memenuhi kriteria-kriteria, seperti uji validitas, reliabilitas, daya beda dan indeks kesukaran.

Tes yang akan digunakan untuk mengukur penguasaan kompetensi pengetahuan berupa tes objektif dalam bentuk pilihan ganda biasa dilakukan pengujian instrumen yaitu uji validitas, reliabilitas, daya beda dan indeks kesukaran. Hasil validasi akan diberikan kepada siswa kelompok eksperimen dan kelompok kontrol untuk mengetahui kemampuan kompetensi pengetahuan PPKn. Suatu instrumen (tes) dikatakan valid jika instrumen tersebut dapat digunakan untuk mengukur apa yang seharusnya diukur. Uji validitas empirik tes kompetensi pengetahuan PPKn dalam bentuk objektif hanya dilakukan berupa uji validitas butir. Untuk mengukur validitas butir tes kompetensi pengetahuan PPkn dalam bentuk tes objektif digunakan rumus koefisien korelasi point biserial (rpbi). Selain uji validitas, syarat lainnya adalah uji reliabilitas.

Reliabilitas merupakan tingkatan atau derajat konsistensi dari suatu instrumen. Suatu instrumen penelitian dikatakan mempunyai nilai reliabilitas yang tinggi, apabila tes yang dibuat mempunyai hasil yang konsisten dalam mengukur yang hendak diukur. Tes dalam penelitian ini bersifat dikotomi sehingga rumus yang digunakan untuk uji reliabilitas tes adalah rumus Kuder Richardson (K-R. 20). Pemberian interpretasi terhadap koefesien reliabilitas tes $\mathrm{r} 11\urcorner$ digunakan patokan, yakni (1) apabila $\mathrm{r} 11-\geq 0,70$ berarti tes penguasaan kompetensi pengetahuan yang sedang diuji reliabilitas dinyatakan reliable, (2) apabila r11- < 0,70 berarti tes yang sedang diuji reliabilitasnya tersebut dinyatakan unreliable. Sehingga didapatkan 30 butir test yang sudah divalidasi.

Data yang terkumpul dalam pelaksanaan penelitian ini perlu dianalisis. Teknik analisis yang digunaka $\mathrm{n}$ untuk menganalisis data hasil penelitian ini adalah teknik analisi gain skor dinormalisasi dari nilai pretest dan posttest. Analisis data yang sudah didapat menggunakan analisis statistik deskriptif dan statistik inferensial. Statistik deskriptif adalah statistik yang digunakan untuk menganalisis data dengan cara mendeskripsikan data yang telah terkumpul sebagaimana adanya tanpa membuat kesimpulan yang berlaku untuk populasi di mana sampel diambil (Sugiyono, 2012: 207). Penyajian data dalam penelitian ini dengan pendekatan Penilaian Acuan Normatif (PAN) yang menggunakan perhitungan statistik Mean $(M)$ dan Standar Deviasi $(s)$. Statistik inferensial adalah teknik statistik yang digunakan untuk menganalisis data sampel dan hasilnya diberlakukan untuk populasi (Sugiyono, 2012:209). Sebelum dilakukan uji hipotesis dengan statistik inferensial menggunakan statistik parametrik, data yang akan dianalisis harus mememnuhi beberapa prasyarat yaitu uji normalitas sebaran data dan uji homogenitas varians.

Uji normalitas sebaran data menggunakan teknik kolmogorov-smirnov untuk mengetahui apakah data sampel yang diambil berdistribusi normal atau data tersebut 
signifikan dengan populasi dimana sampel tersebut diambil. Kriteria dalam pengujian untuk teknik kolmogorov-smirnovyaitu apabila nilai $\mathrm{A}_{1}$ maksimum $\leq$ nilai tabel kolmogorov-smirnov pada taraf signifikansi $5 \%$ dengan $\mathrm{N}=$ jumlah sampel, maka data berdistribusi normal. Sedangkan untuk uji homogenitas varians dipergunakan untuk mengetahui sama atau homogennya nilai secara statistik. Salah satu uji homogenitas varians yang dapat dipergunakan adalah uji $(F)$.Dengan kriteria harga $F$ hitung yang diperoleh kemudian dibandingkan dengan harga $F$ tabel. Kriteria pengujian, jika $F_{h i t}<F_{\text {tabel }}$ maka sampel homogen. Uji dilakukan pada taraf signifikansi $5 \%$ dengan derajat kebebasan untuk pembilang $\mathrm{n}_{1}-1$ dan derajat kebebasan untuk penyebut $\mathrm{n}_{2}-1$ (Sugiyono, 2012: 275). Jika data yang diperoleh sudah memenuhi prasyarat uji normalitas dan homogenitas yaitu data berdistribusi normal dan varians homogen maka analisis yang digunakan adalah statistik parametrik. Uji statistik parametrik yang digunakan adalah uji beda mean (uji-t) dengan pooled varian.

\section{Hasil dan Pembahasan}

Data yang dideskripsikan pada hasil penelitian ini adalah data kompetensi pengetahuna PPkn pada kelompok siswa kelas V SD Negeri 13 Sesetan sebagai kelompok eksperimen yang dibelajarkan menggunakan model pembelajaran kooperatif tipe scramble berbantuan media video animasi. Dan kelompok siswa kelas V SD Negeri 2 Serangan sebagai kelompok konrol. Hasil pretetsberupa tes objektif sebagai tes awal samlpel penelitian sedangkan posttestsdiberikan pada ahkir penelitian setelah 6 kali perlakukan di kelompok ekperimen dan kelompok kotrol. Berdasarkan hasil analisis kompetensi pengetahun PPkn kelompok ekperimen gain scor ternormalisasi memiliki rata-rata lebih tinggi dari pada kelas kontrol yaitu, $\overline{\mathrm{X}} 1=0,309>\overline{\mathrm{X}} 2=0,196 . \mathrm{Uji}$ prasyarat dalam penelitian sebagai syarat dipergunakanya statistik parametrik seperti pengujian hipotesis dengan menggunakan uji-t. uji prasyarat tersebut terdiri dari uji normalitas sebaran data dan uji homogenitas varians.

Uji normalitas sebaran data untuk megetahuan PPKn menggunakan teknik kolmogorovsmirnov.Denga kriteria dalam pengujian untuk teknik kolmogorov-smirnovyaitu apabila nilai $\mathrm{A}_{1}$ maksimum $\leq$ nilai tabel kolmogorov-smirnov pada taraf signifikansi $5 \%$ dengan $\mathrm{N}=$ jumlah sampel, maka data berdistribusi normal.

Berdasarkan hasil uji normalitas kelompok ekperimen diperoleh $A_{\max }=0,111$. pada taraf signifikan $5 \%$ dan $\mathrm{n}=38$ diperoleh table kolmogorov-smirnovadalah 0,215 . Hal ini menunjukan bahwa $0,111<0,215$ maka sebaran data nilai gain scor berdistribusi normal.

Dan normalitas sebaran data kelompok kontrol diperoleh $\mathrm{A}_{\max }=0,181$ pada taraf signifikan $5 \%$ dan $n=39$ diperoleh table kolmogorov-smirnovadalah 0,213 . Hal ini menunjukan bahwa 0,181 <0,213 maka sebaran data nilai gain scor berdistribusi normal.

Setelah data kedua kelompok kelas berdistribusi normal, dilanjutkan dengan uji homogenitas varians data kedua kelompok kelas. Tujuannya uji homogenitas ini untuk mengetahui apakah data kedua kelompok kelas homogen atau tidak. Hasil pengujian menunjukkan bahwa diperoleh nilai $F_{\text {hitung }}=1,66$. Adapun nilai $F_{\text {tabel }}$ pada taraf signifikansi 5\% dengan $\mathrm{dk}_{\text {pembilangn1-1 }}=37$ dan $\mathrm{dk}_{\text {penyebut }}=\mathrm{n} 2-1=38$ adalah 1,72, sehingga perbandingan $F_{\text {hitung }}<F_{\text {tabel }}$ yaitu $1,66<1,72$. Sesuai dengan pengujian tersebut data kelompok kelas eksperimen dan kelompok kelas kontrol homogen.

Tabel 1. Hasil Statistik Deskritif 


\begin{tabular}{lcc}
\hline Statistik Deskriptif & $\begin{array}{c}\text { Kelompok } \\
\text { eksperimen }\end{array}$ & $\begin{array}{c}\text { Kelompok } \\
\text { Kontrol }\end{array}$ \\
\hline $\mathrm{N}$ & 38 & 39 \\
Mean (M) & 0,309 & 0,196 \\
Standar Deviasi & 0,197 & 0,153 \\
Varians & 0,0389 & 0,0234 \\
\hline
\end{tabular}

Hasil uji prasyarat menunjukkan bahwa data kelompok kelas eksperimen maupun kontrol berdistribusi normal dan memiliki varians yang homogen, karena data yang diperoleh telah memenuhi uji prayarat maka statistik parametrik dengan uji t untuk uji hipotesis dapat dipergunakan. Adapun hipotesis yang akan diuji pada penelitian ini yaitu tidak terdapat perbedaan signifikan kompetensi pengetahuan PPKn antara kelompok siswa yang dibelajarkan melalui model pembelajaran kooperatif tipe scramble berbantuan media video animasi dan kelompok siswa yang dibelajarkan secara konvensional pada siswa kelas V SD Gugus V Jenderal Judirman Denpasar Selatan Tahun Ajaran 2018/2019.

Hasil analisis uji-t diperoleh thitung $=2,825$. Sedangkan nilai ttabel pada taraf signifikansi $5 \%$ dengan $\mathrm{dk}=\mathrm{n}_{1}+\mathrm{n}_{2}-2=38+39-2=75$ menunjukkan nilai tabel sebesar 1,992 . Sehingga diperoleh hasil analisis nilai thitung $=2,825>$ tabel $=1,992$ maka $\mathrm{H}_{0}$ ditolak dan $\mathrm{H}_{\mathrm{a}}$ diterima.

Tabel 2. Rangkuman Hasil Uji-t

\begin{tabular}{ccccc}
\hline Kelompok & $\mathrm{N}$ & $\mathrm{Dk}$ & $\mathrm{t}_{\text {hitung }}$ & $\mathrm{t}_{\text {tabel }}$ \\
\hline Eksperimen & 38 & 75 & 2,825 & 1,992 \\
\hline Kontrol & 39 & & & \\
\hline
\end{tabular}



Berdasarkan hasil analisis $t_{\text {hitung }}=2,825>t_{\text {tabel }}=1,992$ maka $h_{0}$ ditolak. Hal ini berarti terdapat perbedaan yang signifikan kompetensi pengetahuan PPKn antara kelompok siswa yang dibelajarkan menggunakan model pembelajaran kooperatif tipe scramble berbantuan media video animasi dan kelompok siswa yang dibelajarkan menggunakan pembelajaran secara konvensional pada siswa kelas V SD Gugus V Jenderal sudirman Denpasar Selatan Tahun Ajaran 2018/2019. Karena terdapat perbedaan yang signifikan, maka hal tersebut berarti model pembelajaran kooperatif tipe scamble berbantuan media video animasi berpengaruh terhadap kompetensi pengetahuan PPKn pada siswa kels v SD gugus V Jenderal Sudirman Denpasar selatan TahunAjaran 2018/2019.

Dengan demikian, model pembelajaran kooperatif tipe scramble berbantuan media video animasi dapat direkomendasikan dalam membelajarkan siswa khususnya pada kegiatan pembelajaran yang berisi muatan materi PPKn. Dimana dalam proses pembelajaran dapat membangun pengetahuan siswa dan meningkatkan kerjasama siswa melalui kegiatan diskusi dan menjawab soal-soal yang diberikan melalui permainan sehingga pembelajaran menjadi lebih menyenangkan dan bermakna. Model pembelajaran kooperatif tipe scramble berbantuan media video animasi dapat dipergunakan sebagai alternatif dalam strategi pembelajaran dimana model pembelajaran ini merupakan model pembelajaran yang mengajak siswa untuk menemukan jawaban dan menyelesaikan permasalahan yang ada dengan cara membagikan lembar soal dan lembar jawaban yang disertai dengan alternatif jawaban yang tersedia.

Model pembelajaran scramble merupakan model pembelajaran yang mengarahkan siswa untuk menjawab pertanyaan berdasarkan jawaban yang telah tersedia namun masih dalam kondisi jawaban diacak, melalui model pembelajaran ini siswa diharuskan untuk menerka jawaban secara cepat, sehingga dapat membuat siswa semangat, memotivasi siswa dalam belajar. model pembelajaran scramble siswa tidak hanya dilatih itu saja, tetapi siswa juga dilatih dalam berkerjasama antar anggota kelompok untuk saling membantu teman sekelompoknya agar dapat berpikir kritis sehingga dapat lebih mudah dalam mencari penyelesaian soal. Penggunaan model pembelajaran scramble dalam pembelajaran diharapkan dapat meningkatkan minat serta motivasi siswa melalui pembelajaran yang lebih bermakna dan menyenangkan. Adapun kelebihan model pembelajaran kooperatif tipe scramble Menurut Kurniasih dan Sani (2016:100) kelebihan model pembelajaran scramble yaitu, (a) siswa sangat terbantu dalam mencari jawaban, (b) mendorong siswa untuk belajar mengerjakan soal tersebut, (c) semua siswa dapat terlibat aktif, (d) siswa dapat saling membantu dalam memahami materi pembelajaran, dan (e) meningkatkan sikap disiplin siswa.

Sedangkan pada Pembelajaran kelompok kontrol dalam menyampaikan materi kepada siswa hanya diselingi dengan sedikit tanya jawab kemudian diikuti dengan pemberian tugas secara individu. Dengan pembelajaran seperti ini, siswa belum optimal mempunyai kesempatan untuk mengembangkan kemampuan berpikir, kesempatan untuk mengajukan ide yang dimiliki, serta memecahkan masalah yang ditemui. Pembelajaran seperti ini, membuat siswa merasa bosan dan jenuh sehingga sulit untuk memahami materi pelajaran. Dengan demikian, perbedaan hasil kompetensi pengetahuan PPKn siswa dapat terlihat dari keunggulan penerapan model pembelajaran kooperatif tipe scramble berbantuan media video animasi nilai rata-rata gain skor dinormalisasi, dan hasil uji hipotesis dari kelompok kelas eksperimen dan kelompok kelas kontrol.

Penelitian ini relevan dengan penelitian yang dilakukan oleh Sri Vidya (2014) dengan analisis menunjukkan bahwa terdapat perbedaan yang signifikan hasil belajar IPS antara kelompok eksperimen dengan kelompok kontrol siswa kelas V SD Gugus Kapten Kompiang Sujana Denpasar Barat Tahun Ajaran 2013/2014. Hal tersebut dibuktikan dengan hasil thitung=18,58 $>$ ttabel $(\alpha=$ $0,05,83)=2,000$. Selain itu penelitian ini juga mendukung penelitian oleh Novita deviani (2017) yang menyatakan bahwa terdapat pengaruh model pembelajaran kooperatif tipe scramble berabntuan bahan manipulatif terhadap kompetensi pengetahuan matematika siswa kelas IV SD Gugus Letkol Wisnu Denpasar Utara Tahun Pelajaran 2016/2017. Yang dibuktikan dari nilai rata-rata post-test pada kelompok eksperimen sebesar 78,39 sedangkan pada kelompok kontrol sebesar 60,00. Demikian pula 
hasil analisis uji-t yang menunjukkan thitung $=7,27$ dan ttabel $=1,980$ untuk $\mathrm{dk}=91$ dengan taraf signifikansi $5 \%$, sehingga $t_{\text {hitung }}>t_{\text {tabel }}(7,27>1,980)$ dan H0 ditolak.

\section{Simpulan}

Berdasarkan pedoman konversi PAN dengan skala lima dan grafik histogram gain skor ternormalisasi kompetensi pengetahuan PPKn siswa kelas V SD Negeri 13 Sesetan pada kelompok ekperimen diperoleh nilai rata-rata 0,309. Dapat dijelaskan bahwa terdapat 5 Siswa termasuk kategori sangat tidak baik, 8 siswa kategori tidak baik, 17 siswa pada kategori cukup baik, 4 siswa termasuk kategori baik dan 4 siswa termasuk kategori sangat baik. Berdasarkan hasil tersebut juga dapat dicermati nilai gain skor ternormalisasi siswa kelas $\mathrm{V}$ yang berada dibawah rata-rata sebanyak 13 siswa dan yang mencapai rata-rata sebanyak 25 siswa. kemudian nilai rata -rata gain skor ternormalisasi $\overline{\mathrm{X}} 1=0,309$ dikonversikan pada tabel pengkatagorian kompetensi pengetahuan PPKn kelompok ekperimen pada Penilaian Acuan Norma (PAN) skala lima sehingga dapat diketahui kompetensi pengetahuan PPKn pada siswa V kelompok eksperimen berada pada kategori cukup baik.

Berdasarkan pedoman konversi PAN dengan skala lima dan grafik histogram gain skor ternormalisasi kompetensi pengetahuan PPKn siswa kelas V SD Negeri 2 Serangan pada kelompok kontrol diperoleh nilai rata-rata 0,196. Dapat dijelaskan bahwa tidak terdapat siswa termasuk kategori sangat tidak baik, 16 siswa kategori tidak baik, 17 siswa pada kategori cukup baik, 4 siswa termasuk kategori baik dan 6 siswa termasuk kategori sangat baik. Berdasarkan hasil tersebut juga dapat dicermati nilai gain skor ternormalisasi siswa kelas $\mathrm{V}$ yang berada dibawah rata-rata sebanyak 22 siswa dan yang mencapai rata-rata sebanyak 18 siswa. kemudian nilai rata-rata gain skor $\overline{\mathrm{X}} 1=0,196$ dikonversikan pada tabel pengkatagorian kompetensi pengetahuan PPKn kelompok kontrol pada Penilaian Acuan Norma (PAN) skala lima sehingga dapat diketahui kompetensi pengetahuan PPKn pada siswa V kelompok kontrol berada pada kategori cukup baik.Hasil analisis uji hipotesis menyatakan bahwa terdapat perbedaan yang signifikan nilai gain skor dinormalisasi dari kedua kelompok kelas. Hal ini dibuktikan dengan analisis uji-t diperoleh thitung $=2,825$ sedangkan pada taraf signifikan 5\% dengan $\mathrm{dk}=75$ diperoleh nilai ttabel $=1,992$. Karena thitung $=2,825>\mathrm{ttabel}=$ 1,992 maka H0 ditolak dan hipotesis alternatif $(\mathrm{Ha})$ yang menyatakan terdapat perbedaan yang signifikan kompetensi pengetahuan PPKn antara kelompok siswa yang dibelajarkan melalui model pembelajaran kooperatif tipe scramble berbantuan media video animasi dengan kelompok siswa dibelajarkan secara konvensional pada siswa kelas V SD Gugus V Jenderal Sudirman Denpasar Selatan Tahun Ajaran 2018/2019 diterima. Dari hasil analisis tersebut dapat disimpulkan bahwa model pembelajaran kooperatif tipe scramble berbantuan media video animasi berpengaruh terhadap kompetensi pengetahuan PPKn siswa kelas V SD Gugus V Jenderal Sudirman Denpasar Selatan Tahun Ajaran 2018/2019.

Berdasarkan simpulan dari penelitian, dapat diajukan beberapa saran sebagai tindak lanjut dari penelitian ini. Saran ini diajukan kepada berbagai pihak yang terkait dengan manfaat hasil penelitian. Kepada guru diharapkan dapat lebih kreatif lagi dalam memilih dan menggunakan berbagai model pembelajaran yang inovatif dan kreatif dalam merancang suatu 
pembelajaran untuk dapat memotivasi dan memfasilitasi potensi yang dimiliki oleh siswa sehingga dapat mencapai hasil belajar yang optimal. Inovasi pembelajaran dapat berupa penggunaan model pembelajaran serta media pembelajaran yang inovatif, kepada sekolah diharapkan pihak sekolah mampu mengambil kebijakan yang tepat untuk lebih memaksimalkan upaya peningkatan kemampuan siswa melalui penggunaan model-model pembelajaran yang efektif dan efisien serta berdaya guna bagi perkembangan para siswa dan melaksanakan sosialisasi secara berkelanjutan mengenai inovasi-inovasi pembelajaran kepada guru-guru dalam membelajarkan siswa dengan tujuan perubahan paradigma proses pembelajaran di sekolah yang menunjang kredibelitas menjadi sekolah yang unggul dan inovatif, kepada peneliti lain diharapkan dapat mengadakan penelitian lebih lanjut tentang model pembelajaran scramble berbantuan media video animasi baik dalam bidang ilmu PPKn maupun bidang ilmu lainnya, agar memperhatikan kelemahan yang ditemukan dalam penelitian ini sebagai bahan pertimbangan untuk perbaikan dan penyempurnaan penelitian yang akan dilaksanakan.

\section{Daftar Rujukan}

Agung, A.A Gede. 2014. Metodologi Penelitian Pendidikan. Singaraja: Aditya Media Publishing.

Aryad, Azhar. 2010. Media Pembelajaran. Jakarta: Rajawali Pers.

Kurniasih, Imas Dan Berlin Sani. 2016. Ragam Pengembangan Model Pembelajaran Untuk Meningkatkan Profesionalitas Guru. Jakarta: Kata Pena.

Novita, Ni Luh. 2017. Pengaruh Model Pembelajaran Kooperatif Tipe Scramble Berbantuan Bahan Manipulative Terhadap Kompetensi Pengetahuan Matematika Siswa Kelas IV SD Gugus Letkol Wisnu Denpasar Utara Tahun Pelajaran 2016/2017. Universitas Pendidikan Ganesha, Volume 1, Nomor 2. Tersedia pada ejounal.undiksha.ac.id (diakses pada tanggal 3 maret 2019)

Permendikbud. 2014. Peraturan Menteri Pendidikan dan Kebudayaan Republik Indonesia Nomor 57 Tahun 2014 Tentang Kurikulum 2013 Sekolah Dasar/Madrasah Ibtidaiyah. Jakarta: Kementrian Pendidikan dan Kebudayaan.

Sisdiknas. 2003. Undang-undang RI No. 20 tahun 2003 Tentang Sistem Pendidikan Nasional. Jakarta.

Sri Vidya ArtiniA. A. Ayu. 2014. Pengaruh Model Pembelajaran Kooperatif Tipe Scramble Berbantuan Media Semi Konkret Terhadap Hasil Belajar IPS Siswa Kelas V SD Gugus Kapten Kompiang Sujana Denpasar Barat Tahun Ajaran 2013/2014. Universitas 
Pendidikan Ganesha, Volume 2, Nomor 1. Tersedia pada ejounal.undiksha.ac.id (diakses pada tanggal 30 mei 2019)

Sudijono, Anas. 2015. Pengantar Evaluasi Pendidikan. Jakarta: PT Rajagrafindo Persada.

Widiantari Ni Nym. Pengaruh Model Pembelajaran Scramble Berbantuan Media Video Terhadap Hasil Belajar IPA Siswa Kelas IV SD Di Gugus V Kecamatan Buleleng Tahun Pelajaran 2012/2013. Universitas Pendidikan Ganesha, Volume 1, Nomor 1. Tersedia pada ejounal.undiksha.ac.id (diakses pada tanggal 30 mei 2019).

Widiatuti Ni Kadek. 2017. Pengaruh Model Pembelajaran Kooperatif Tipe Scramble Berbantuan Mind Mapping Terhadap Hasil Belajar IPS Pada Siswa Kelas V SD Di Gugus I Kecamatan Banjar Kabupaten Buleleng Tahun Pelajaran 2016/2017. Universitas Pendidikan Ganesha, Volume 5, Nomor 2. Tersedia pada ejounal.undiksha.ac.id (diakses pada tanggal 30 mei 2019). 